\title{
Early Development of Gerbera as a Floricultural Crop
}

\author{
Kenneth R. Tourjee, James Harding, and Thomas G. Byrne
}

Additional index words. Gerbera jamesonii, Gevbera viridifolia, Compositae, plant breeding, history, crimson daisies

Summary. The development of gerbera ( Gerbera jamesonii H. Bolus ex. Hooker) as a floricultural crop is traced from its collection as a botanical novelty in South Africa to its establishment as a commercial crop in the 1930s. The origin of the cultivated germplasm, G. jamesonii and G. viridifolia (DC) Schultz- Bipontinus, is discussed, as well as breeding work that occurred in Europe and the United States. The contributions of the two species to the cultivated germplasm is unknown. Early breeding in Europe was conducted by RI. Lynch at the Cambridge Botanic Gardens in England, R. Adnet at La Rosarie in Antibes, France; and by C. Sprenger in Italy. In the United States, early work was done at estates in New Jersey by Herrington and Atkins, and by the commercial growers Jaenicke and the J.L. Childs' Seed Co. Establishing the cold hardiness of the crop for temperate climates was an early goal of horticulturists and breeders. Much of the cultivated germplasm can be traced to material that passed through Cambridge and Antibes.

G erbera is an important floricultural crop in the United States and worldwide, both as a cut flower and garden plant. Its importance is reflected in statistics describing both the production and value of the crop. In 1988, Florida produced 3 million plantlets for the nursery trade, and the United States imported 33,000 stems for the florist trade (Rogers and Tjia, 1990). The shipping point price of stem imports through Miami, Fla., ranged from $\$ 0.15 /$ stem in July to $\$ 0.35 /$ stem in Sept. 1988 , while the San Francisco wholesale market price

Environmental Horticulture Department, University of California, Davis, CA 95616-8587,

The cost of publishing this paper was defrayed in part by the payment of page charges. Under postal reguations, this paper therefore must be hereby marked advertise ment solely to indicate tbis fact. per stem ranged from $\$ 0.35$ in April to $\$ 0.60$ in Nov. 1988 (Federal-State Market News Service, 1988 ).

Major exporters to the United States in 1988 were Colombia, The Netherlands, Costa Rica, Israel, and the Dominican Republic. Colombia and The Netherlands claimed $63 \%$ and $15 \%$ of the United States import total, respectively (Federal-State Market News Service, 1988). The Netherlands averaged $>200,000 \mathrm{~m}^{2} /$ year of gerbera under. cultivation from 1980 to 1991 (Netherlands Central Bureau of Statistics, 1992). This production ranks it between orchids $\left(180,000 \mathrm{~m}^{2}\right)$ and carnations $\left(250,000 \mathrm{~m}^{2}\right)$ in terms of area under cultivation, and is $>20 \%$ of the area dedicated to roses in The Netherlands (Netherlands Central Bureau of Statistics, 1992).

The development of the crop can be traced to the late 19 century, when it was introduced first to Europe and the United States from southern Africa (Dümmer, 1914; Herrington, 1901 ). The breadth of its germplasm base is unknown, but the early literature suggests that the modern crop represents a fairly narrow genetic base. Much of the early literature is inaccessible to the various index services, and no comprehensive literature review exists. The modern literature has been reviewed by Bowe et al. ( 1969), Quagliotti and Baldi (1979), and Rogers and Tjia (1990).

\section{Taxonomy and ecology}

Gerbera is a herbaceous perennial with the source of cultivated germplasm being G. jamesonii and G. viridifolia. The genus was established in 1737 by Gronovius, and commemorates Traug Gerber, an 18th century German naturalist (Dümmer, 1914). The genus contains $\approx 70$ species distributed from southern Africa and Madagascar to eastern Asia. It is a member of the Composite family (tribe Mutisieae, subtribe Mutisiinae), and is divided into seven sections. G. jamesonii, together with G. ambigua (Cass.) Schultz-Bip., G. aswantiaca SchultzBip., G. galpinii Klatt, and G. 
viridifolia, comprise the Lasiopus (Cass.) Schultz-Bip. section of the genus (Hansen, 1985).

The distribution of G. jamesonii is restricted to southern Africa (between lat. $20^{\circ} \mathrm{S}$ and $30^{\circ} \mathrm{S}$, and east of long. $25^{\circ} \mathrm{E}$ ), where it is endemic to Transvaal and Swaziland. It is found in bushveld and steep slopes, on dolomitic and stony clay soils, and on burnt ground and dry, shaded habitats (Hansen, 1985).

G. viridifolia has a broader distribution that ranges along eastern Africa (between lat. $5^{\circ} \mathrm{S}$ and $35^{\circ} \mathrm{S}$, and east of long. $25^{\circ} \mathrm{E}$ ), in open grassland with stony soil. Its two subspecies are G. viridifolia ssp. viridifolia and G. viridifolia ssp. natalensis (Schultz-Bip.) H.V. Hansen comb. et stat. nov. Natural hybrids between G. jamesonii and G. viridifolia are not known (Hansen, 1985). However, there is a report of natural hybridization among G. discolor Harvey, G. plantaginea Harvey, and G. viridifolia (Moss, 1930). G. discolor and G. plantaginea are now included under G. ambigua and G. viridifolia, respectively (Hansen, 1985 ).

\section{Introduction to Europe}

Gerbera jamesonii was discovered by William Greenstock in the summer of 1875-76 in the Houtbosch area of the Transvaal, but Anton Rehmann, an Austrian, is often given credit for its discovery in the summer of 1879-80. However, it was not described until Robert Jameson, a prominent manufacturer of jams and condiments in Durban, collected specimens while on a gold expedition to the Barberton area in 1884. He took the plants to the Durban Botanical Garden, where the director, John Medley Wood, sent material to Harry Bolus in Cape Town for identification. Bolus collected additional material in 1886 and sent it to J.D. Hooker of the Royal Botanical Garden at Kew, with the request that it be named after Jameson. Wood sent live material to Kew in 1888, and one plant survived to flower in the greenhouse in the spring of 1889 . This plant is the source of an illustration (Fig. 1 ) that appeared in Hooker (1889), and serves as the citation for the name Gerbera jamesonii $\mathrm{H}$. Bolus ex Hooker (Codd, 1979). However, two earlier descriptions of G. jamesonii were published, one by R.W. Adlam of South Africa, and the other by Justin Allen of Kew(Adlam, 1888; Allen, 1889; Codd,

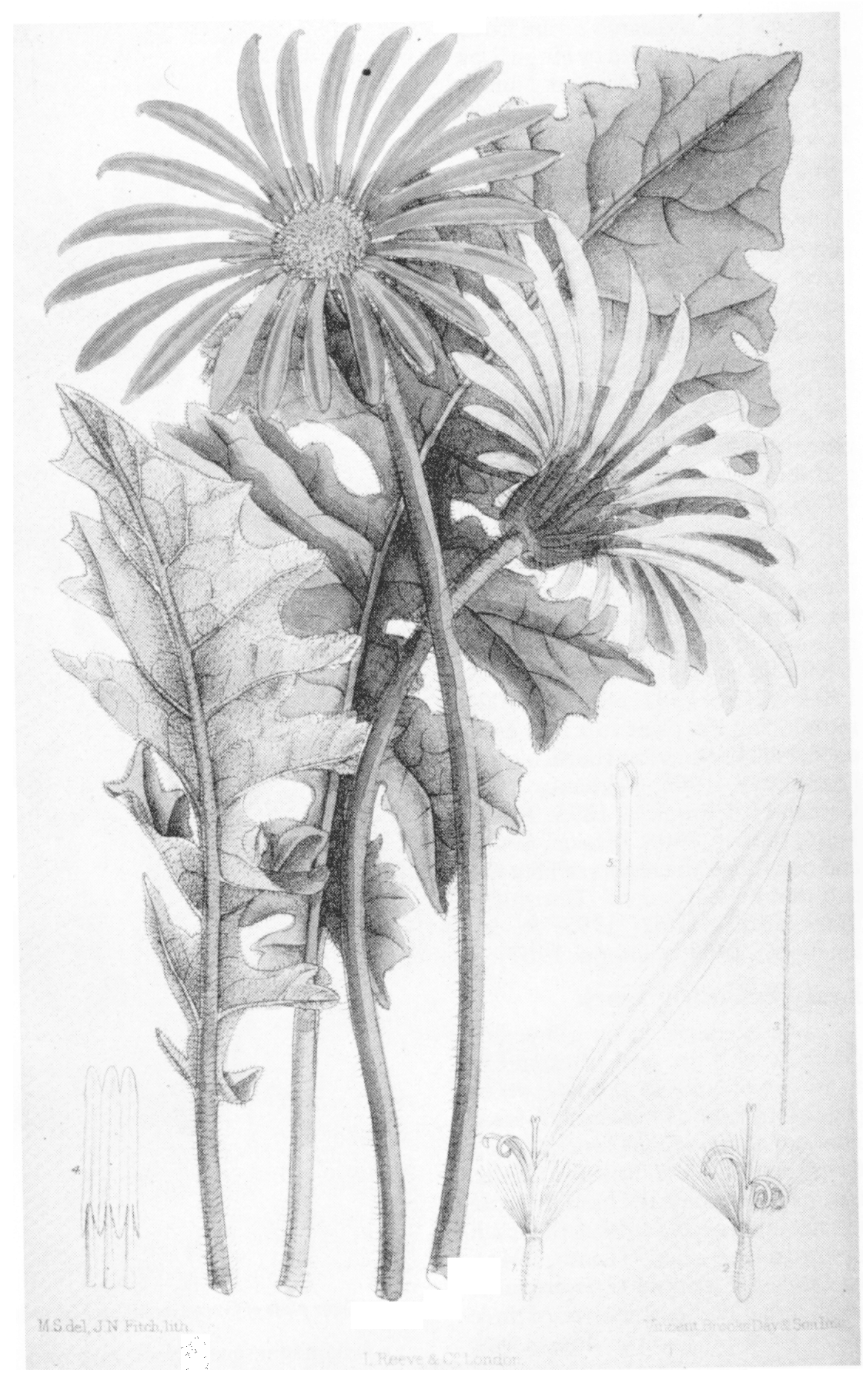

Fig. 1. Reproduction of plate \#7087 from the 1 Nov. 1889 issue of Curtis' Botanical Magazine.

1979; Hansen, 1985).

Seeds were sent to England from South Africa by George Thorncroft in 1887, possibly to Mr. Tillett of Norwich, who grew and provided them to Kew. Richard Irwin Lynch, the curator of the Cambridge Botanic Garden, also received seeds from Adlam (Codd, 1979; Lynch, 1905 ). Those seeds produced a plant with yellow flowers that Lynch named Sir Michael. Lynch maintained the plants at Cambridge, and the Royal Horticultural Society awarded him a First Class Certificate for bright orange-red gerbera cut flowers displayed in Nov. 1891 (Royal Horticulture Society, 1891 ).

By 1910, the hardiness of the crop and basic horticultural requirements were well-established. It was a popular outdoor plant along the Riviera (Adnet, 1907; Bowe et al., 1969 Gardeners' Chronicle, 1907). It remained a novelty in England, probably due to 
its inability to withstand severe frosts, though it was marketed by Hugh, Low and Co., and Bush Hill Park Nursery as early as 1902 (Bowe et al., 1969; Lonsdale, 1908; Nichols, 1902). Typically, dormancy was induced in climates with cold winters by withholding water from the plant in the late fall, and then covering it with ash or dried leaves over winter (Ewbank, 1895; Fairbank, 1958; Jenkins, 1902).

Dümmer lists 44 references to gerbera between 1888 and 1911 in his 1914 revision of the genus (Dümmer, 1914). Early literature on gerbera appeared in both the Gardeners'Chronicle and the Journal of the Royal Horticulture Society from the late 1880s through 1910. Most of the literature can be classified under three categories: Defining cultural techniques to establish the plant for gardens in temperate regions (Adnet, 1907, 1909b; Arnott, 1900; Ewbank, 1895; Hindmarsh, 1902; Jenkins, 1902; Nichols, 1902); introducing the plant to a new audience (both botanical and horticultural) (Burt-Davy, 1906; Fairbank, 1958; Gardeners' Chronicle, 1895; Lynch, 1909; Mottet, 1903; Watson, 1906); and describing the results of breeding programs (Gardeners' Chronicle, 1909; Lynch, 1902, 1905; Review Horticole, 1909; Vilmorin, 1909).

\section{Early breeding work}

Lynch embarked on a breeding program with the goal of extending the range of color in $\mathrm{G}$. jamesonii by producing hybrids between G. jamesonii and G. viridifolia (Lynch, 1905). George Lamb, the Botanic Garden foreman, described the basis for making the interspecific cross as the result of "irregular spacing" (Lamb, 1944). In 1891, the stock of G. jamesonii at the Botanic Garden consisted of three plants placed in a border along a wall; two of the plants were together at one end of the border, the third placed some distance away at the other end of the border. These plants were used to produce seed for distribution to nurseries and botanic gardens. The large number of requests for seed resulted in attempts to increase seed production by bending one flower over another to ensure pollination. However, this technique required that a flower from one of the two plants be sacrificed to pollinate the third more-distant plant, because the plants were believed to be self-sterile.

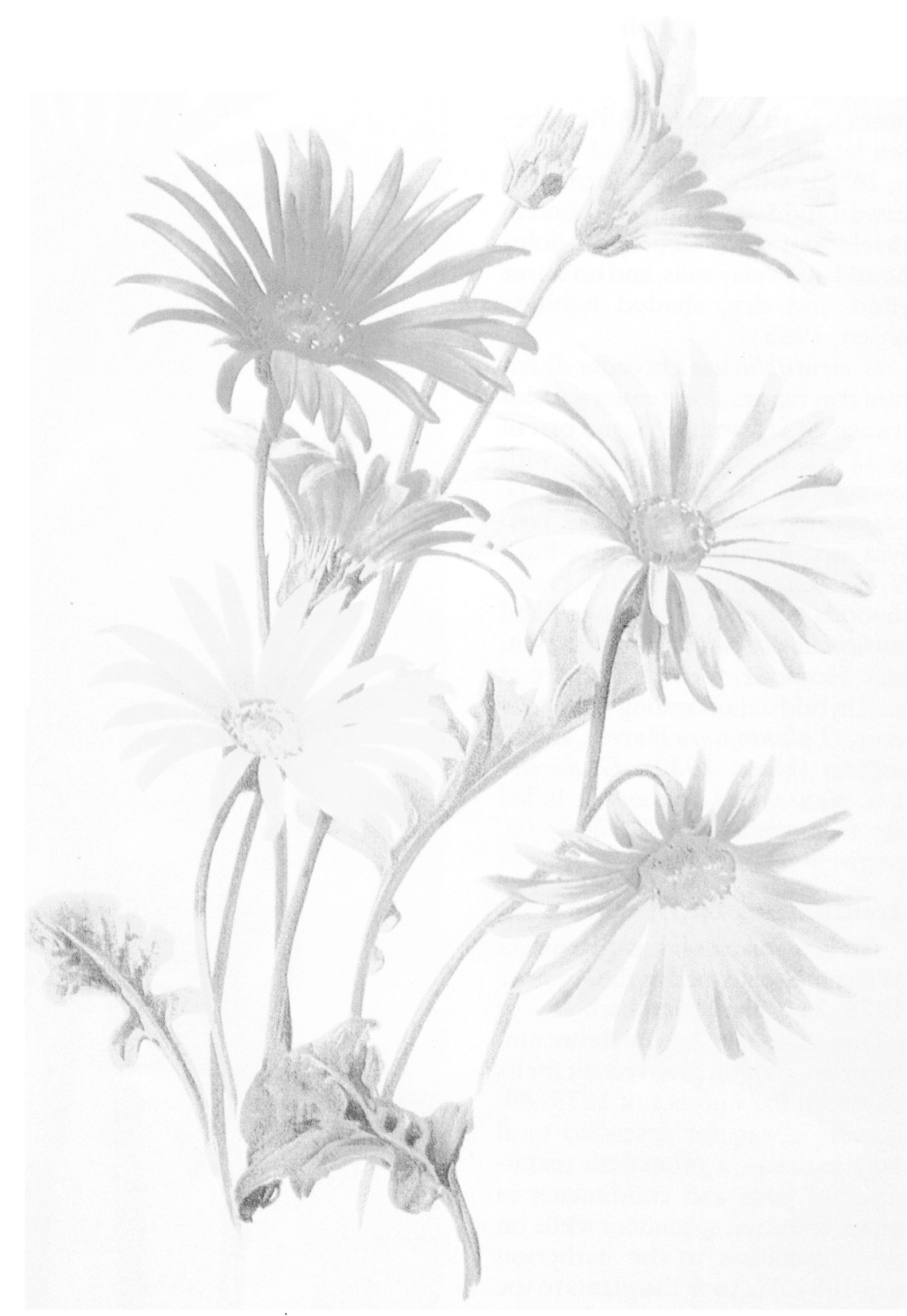

Fig. 2. Color plate of G. jamesonii and G. viridifolia hybrids from Lynch (1905).

Adlam sent several packets of seed to Lynch in 1894 labeled "believed Gerbera sp." (Lamb, 1944; Lynch, 1896). These were subsequently identified at Kew tier germination as G. viridifolia. Lynch suggested that this plant be used to cross to the solitary G. jamesonii plant to avoid wasting flowers, and viable hybrid seeds resulted from the cross. These hybrid gerbera have been referred to variously as Gerbera jamesoni hybrids (Gallet, 1910), Gerbera jamsonii hybrids (Lamb, 1944), hybrids of Gerbera jamesoni (Adnet, 1909a, 1909b), gerbera hybrids (Dubois, 1914), and hybrid ger- beras (Lynch, 1909). In 1904, Lynch was awarded a silver cup at the Royal Horticultural Society's Temple Show for the hybrid gerbera flowers (Fig. 2).

Lynch believed that crossing G. jamesonii to $G$. viridifolia extended the color range of gerbera flowers to white and pink (Lynch, 1905). However, a report appeared in the Gardeners' Chronicle (Lynch 1906; Watson, 1906) that Mr. A.E. Graham-Lawrance had found the full range of colors, including. white and pink, in feral G. jamesonii plants.

By 1905, Lynch turned over his breeding stock to Veitch and Sons 
Nursery, who continued the breeding work (Lynch, 1905). However, the 1906 edition of Hortus Veitchii contains no mention of gerbera (Veitch, 1906). Vilmorin also received stock from Lynch, and had listed varieties of Lynch's hybrid gerberas in the holdings of his catalog (Vilmorin, 1906). Vilmorin described the plants as unproductive and not hardy.

Lynch did not maintain Mendelian records of the crosses he made, but $\mathrm{R}$ Adnet, who had been breeding $\mathrm{G}$. jamemnii at "La Roserai" in Cap D'Antibes, kept such records (Lynch, 1909). He recorded the color of both parents of the plants in his breeding program and the frequencies of color classes among the progeny (Adnet, 1909a; Gardeners' Chronicle, 1909). Adnet received three hybrid plants from Lynch's stock and made 2700 crosses. He had a fourth-generation population of almost 25,000 seedlings with a wide color range (Adnet, 1909a; Dümmer, 1914).

Varieties from Adnet's breeding program were displayed in shows in Berlin, London, and Paris, and growers from Frankfurt received his material (Bowe et al., 1969). His breeding program was continued by E. Dubois and Roberto Diem. Dubois developed several varieties of gerbera (Fig. 3) that were true-breeding for doubled flowers (Dental, 1921; Dubois, 1914). These varieties later were taken to New Zealand by Charles Maire, and contributed to the germplasm of the modem New Zealand varieties (Robinson, 1956), Diem set up a breeding program on the Italian Riviera at Vallercrosia and, by 1920, gerbera were grown commercially in Italy (Cocozza and Puccini, 1979).

Varieties of G. jamesonii also were produced in Naples, Italy, by $\boldsymbol{C}$. Sprenger, and in Belgium (Gardeners' Chronicle, 1909; Vilmorin, 1909). Sprenger obtained his plants directly from South Africa, and is one of the few workers to report the source of his germplasm (Sprenger, 1906). There is a report that W.E. Gumbleton, an Irish horticulturist, received plants from Sprenger (American Gardening, 1902).

Gerbera breeding in The Netherlands was done as early as 1947 by Alkemade und Sohn in Nordwijk (Mücke, 1956). They introgressed a plant obtained from Tasmania into their germplasm, and obtained types with rich, red colors. By 1951, com-

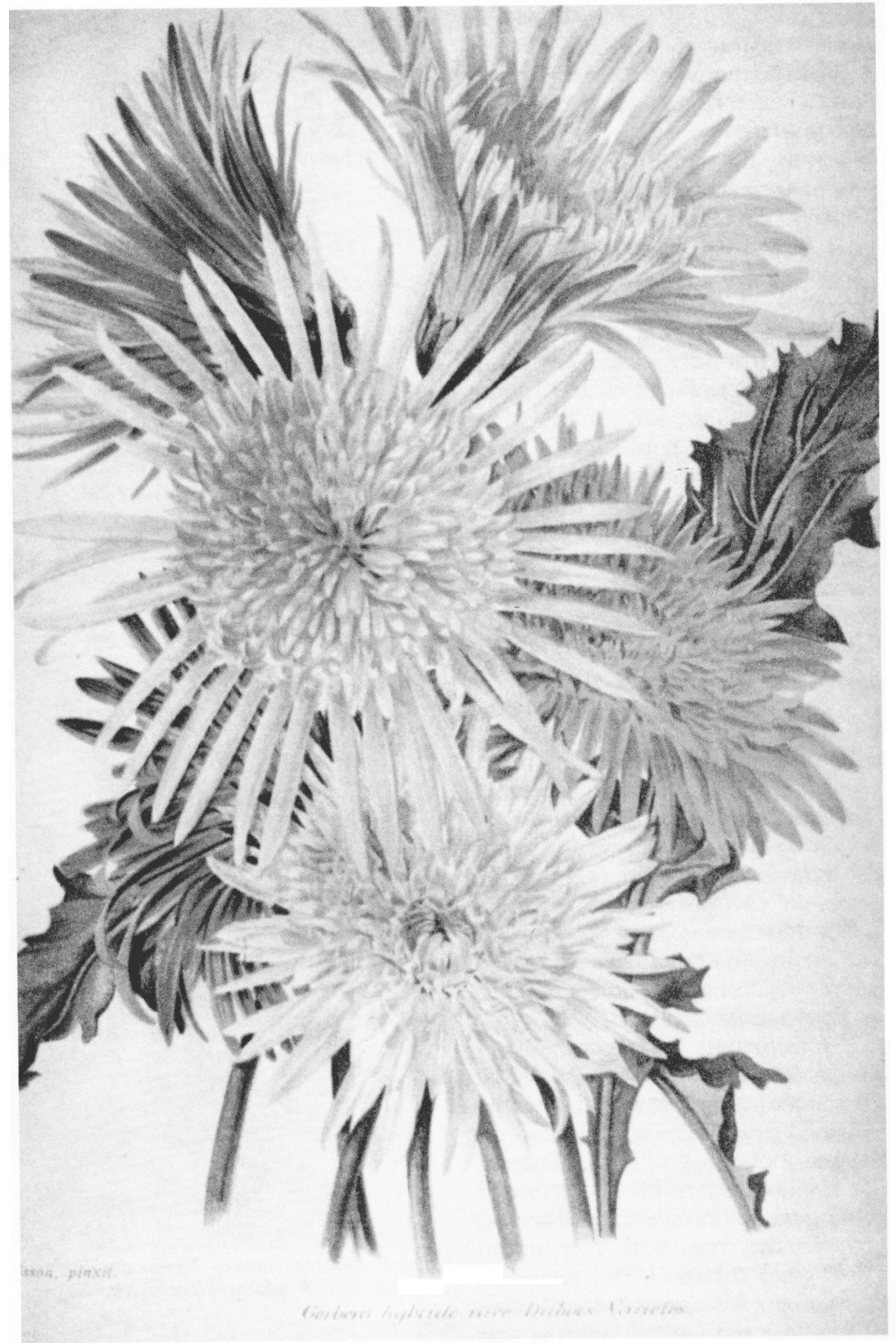

Fig. 3. Varieties of double-flowered gerbera developed by Dubois and Dental, from an illustration in Dental (1921).

mercial growers in The Netherlands had $20,000 \mathrm{~m}^{2}$ of gerbera under glass (Codd, 1979).

\section{Early American literature}

The early American literature focused on introducing the crop to the American audience (Adlam, 1902; Aplin, 1928; Bailey, 1915; Coombs, 1936; Herrington, 1901; Post, 1949), cultural techniques (Atkins, 1901, 1902; Zimmerman and Hitchcock 1934), and plant pathology (Blanton, 1942; Post, 1935; Smith, 1939;
Tompkins, 1937). The American literature does not mention hybrids between G. jamesonii and G. viridifolia (Herrington, 1901; Jaenicke, 1908b; Weston, 1908) until Zimmerman and Hitchcock (1934). However, J.L. Childs' Seed Co. of Floral Park, N.Y., listed the hybrids on p. 37 in the 1911 edition of their catalog (Childs', 1911).

Gerbera were introduced to America through estates located in New Jersey and Rhode Island (Brunton, 1902; Herrington, 1901 ). An early description of $G$. jamesonii in the 
American literature appears in American Gardening (Herrington, 1901). Arthur Herrington, an immigrant estate gardener from England, grew gerbera in Madison, N.J., from 1897. He is possibly the earliest grower of gerbera in America (Lonsdale, 1908). His display of gerbera won the $\$ 50$ novelty prize of the first annual meeting and exhibition of the Horticultural Society of New York at the Botanic Garden, Bronx Park, in May 1901. Frank Brunton, who had grown gerbera in eastern England as early as 1893, grew them in Newport, RI., as a bedding plant in the summer of 1900 (Brunton, 1902). Neither Brunton nor Herrington indicated the source of their plant material, but it is interesting to speculate that their material had been received from the Cambridge Botanic Garden. This would be a further indication of the narrowness of the germplasm base.

According to Atkins (1902), thousands of gerbera plants had been distributed in the United States by 1902. However, gerbera do not appear in Bailey's 4th edition of the Cyclopedia of American Horticulture (1906), but do appear in his 1915 edition of the Standard Cyclopedia of Horticulture. Bailey described G. jamesonii as wellknown in America, and sometimes found outside the collections of botanic gardens and fanciers.

Information on gerbera pollination biology is given by Atkins ( 1901 ). He stated that up to 94 seeds could be obtained from a single cross, and remarked about the protogynous nature of the inflorescence. He also provided some general horticultural advice on growing the crop. Both Herrington (1901) and Atkins (1901) remarked that gerbera were not produced commercially in the United States at that time, and Atkins stated that they would not be commercially viable as a cut flower at carnation prices. In 1904, the New York wholesale price of standard variety carnations during the Christmas season ranged from $\$ 2$ to $\$ 3$ per 100 stems (Florists' Exchange, 1905 ).

Early commercial growers of gerbera in America included J.L. Childs' Seed Co., Henry Dreer, and Adolph Jaenicke (Lonsdale, 1908). Gerbera plants, listed as crimson daisies (Fig. 4), first appeared in the Fall 1902 edition of Childs' catalog (Childs, 1902). They were priced at $\$ 0.40$ each. The nursery claimed that their entire

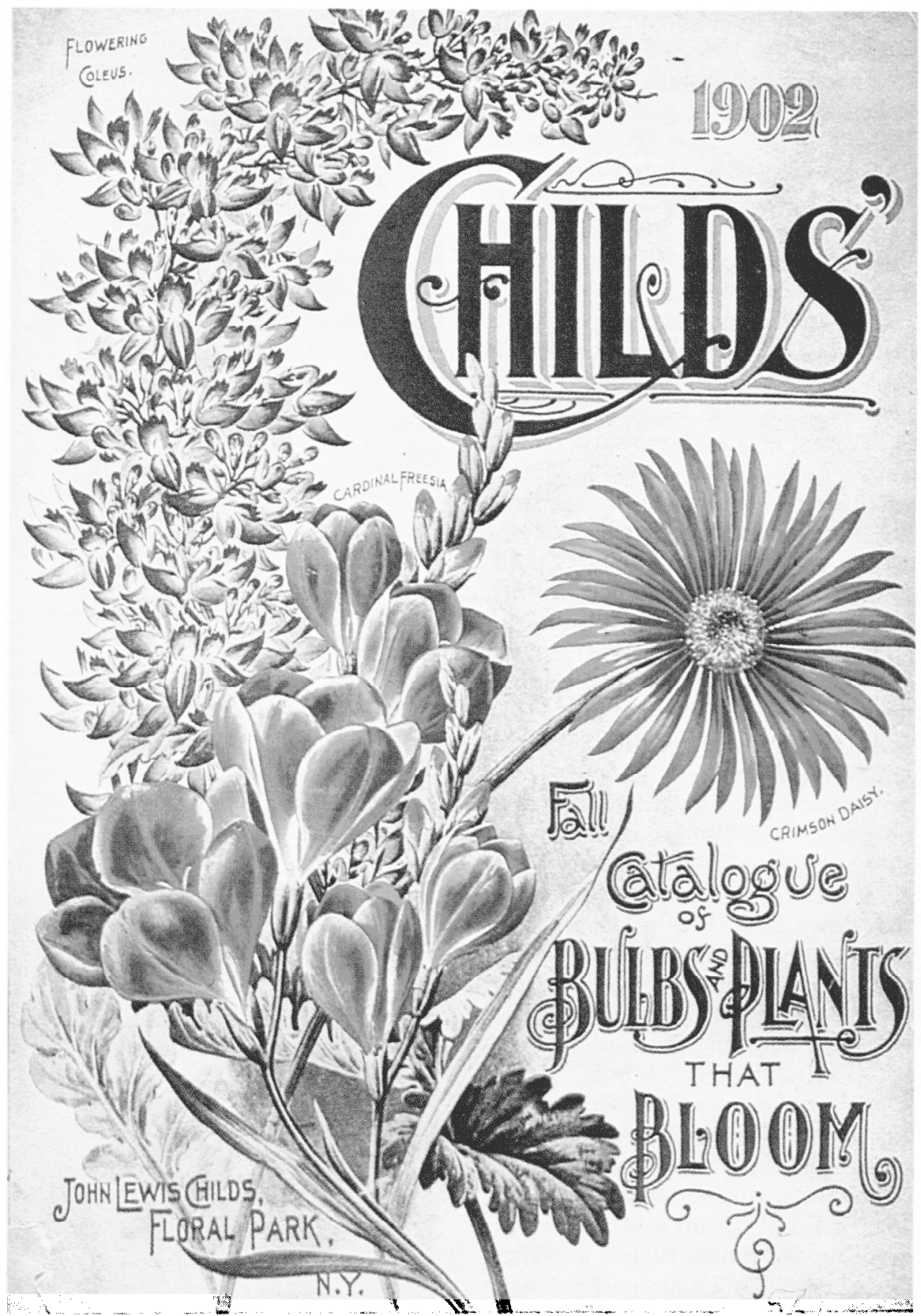

Fig. 4. Gerbera, listed as "crimson daisy," as they appeared on the cover of the Fall 1902 issue of tbe J.L. Childs' catalog, Floral Park, N. Y.

stock was derived from one plant received from a customer in India a few years earlier (Childs, 1902). Jaenicke, a Long Island, N.Y., grower, developed a variety of large-flowered G. jamesonii with improved cold hardiness (Dubois 1914; Jaenicke, 1908a, 1908 b). He named the variety Gerbera jamesoni gigantea, and advertised them for $\$ 15$ per 100 plants in the New York area.

Determining the proper cultural conditions for gerbera paralleled work done in Europe. The establishment of gerbera's cold hardiness was an early obiective (Atkins. 1902: Brunton. 1902; Jaenicke, 1908a; Zimmerman and Hitchcock, 1934). Zimmerman and Hitchcock (1934) determined the cold hardiness of gerbera in an outdoor experiment with 160 plants in Yonkers, N.Y. They compared the effectiveness of different depths of mulch, and found that 8,4 , and 0 inches of mulch resulted in $93 \%, 76 \%$, and $0 \%$ winter survival of plants grown in $10 \times$ $10-\mathrm{ft}$ plots. The 1933-34 winter in question had record cold temperatures reaching $-25 \mathrm{~F}$ in the vicinity of the plots. The plants were grown from 
seed obtained from a Florida commercial grower of G. jamesonii hybrids. Atkins (1902) found that G. jamesonii could not survive the winter in New Jersey as a bedding plant, even when a straw mulch was used. However, he provided no details as to the number of plants nor depth of mulch in his experiments.

By 1908, the popularity of gerbera had declined, and little information is found in the literature until the 1930s (Lonsdale, 1908). Barbara C. Aplin (1928), a California grower, described gerbera as it is grown in southern California as a cut flower crop and a garden plant. This is noteworthy because Dümmer (1914) stated that it was not grown successfully in southern California, possibly due to inadequate horticultural technique.

Gerbera was established as a commercial crop in the United States by the 1930s, as shown by its appearance in plant pathology literature as well as in general textbooks. Reports of diseases caused by Gloeosporum sp. and Botrydis cinerea Pers. (Post, 1934), Phytophthora cryptogen Pethybridge et Lafferty (Tompkins, 193 7), mites (Steneotarsonemus pallides Banks and Polyphagotaronemus latus Banks) (Smith, 1939), and serpentine leaf miner (Agromyza pusilla Meig) (Blanton, 1942) are found in the literature from this period. Textbooks, e.g. Coombs (1936), reported gerbera as a popular cut flower carried by bridesmaids at weddings. Bahr (1937) stated that cut flowers were shipped from California to markets in Chicago. Kenneth Post had a section concerning gerbera in the 1949 edition of Florist Crop Production and Marketing. He described gerbera as primarily a cut-flower crop.

The crop's commercialization continued to spread throughout the world and, by the 1940 s, there were producers in Italy (Cocozza and Puccini, 1979), Germany (Bowe et al., 1969), The Netherlands (Mücke, 1956), New Zealand (Robinson, 1956), South Africa (Fairbank,1958), and the United States (Bahr, 1937; Childs', 1911). The relative contribution of $G$. jamesonii and $G$. viridifolia to the modern gerbera crop is unknown, but much of the cultivated germplasm can be traced to material that passed through Cambridge and Antibes.

\section{Acknowl edgment}

J. Heinrich Leith and Roy M. Sachs kindly translated French" and German literature for this manuscript. Robert L. Geneve provided the reference to J.L. Childs' Seed Co. I also thank the staff of Peter J. Shields Library for their effort in procuring rare texts, and Ron Lane for technical advice.

\section{Literature Cited}

Adlam, R. W. 1888. Colonial notes. The Gardeners' Chron. 3(78):775.

Adlam, R. W. 1902. Gerbera jamesoni. Amer. Gardening 23(367):6.

Adnet, R. 1907. Foreign correspondence. Gardeners' Chron. 41(1046):18.

Adnet, R. 1909a. Les Gerbera jamesoni hybrides et leur culture. Le Jardin, 23(533):136-137.

Adnet, R. 1909b. Les hybrides de Gerbera jamesoni-leur culture. Rev. Hort. 81:230233.

Allen, J. 1889. Gerbera jamesoni. Gardeners' Chron. 5(130):772-773.

American Gardening. 1902. Varieties of Gerbera. Amer. Gardening 23(374):120.

Aplin, B.C. 1928. Gerberas outdoors. Florists' Rev. 63(1622):23-24.

Arnott, S. 1900. Plant notes. Gardeners' Chron. 28(709):64.

Atkins, C.H. 1901. Gerbera jamesoni. Amer. Gardening 22(343):507.

Atkins, C.H. 1902. Cultural needs of Gerbera jamesoni. Amer. Gardening 23(368): 22.

Bahr, F. 1937. Fritz Bahr's commercial floriculture: A practical manual for the retail grower. 4th ed. De La Mare Co. New York.

Bailey, L.H. 1906. Cyclopedia of American horticulture, 4th ed. Doubleday, Page, New York.

Bailey, L.H. 1915. The standard cyclopedia of horticulture. Macmillan, New York.

Blanton, F.S. 1942. Methyl bromide for the control of the serpentine leaf miner in gerbera and notes on the insect's life history. J. Econ. Entomol. 35(1):31-34.

Bowe, R., W. Danhardt, W. Fritzsche, W. Gerstner, and W. Junges. 1969. Gerbera. Verlag J. Neumann-Neudamm, Berlin.

Brunton, F. 1902. Gerbera jamesoni for summer and winter. Amer. Gardening 23(369):39.
Burt-Davy, J. 1906. Colonial notes. Gar deners' Chron. 40(1043):421.

Childs' Seed Co. 1902. Fall catalogue, bulbs and plants that bloom. J.L. Childs' Seed Co., Floral Park, N.Y.

Childs' Seed Co., 1911. Rare flowers, vegetables and fruits catalog. J.L. Childs' Seed Co., Floral Park, N.Y.

Cocozza, M. and G. Puccini 1979. Carnation and gerbera in Italian floriculture, p.7-46. In: L. Quagliotti and A. Baldi (eds.). Proc. Eucarpia Mtg. on carnation and gerbera, Alassio, Italy, Apr. 1978.

Codd, L.E. 1979. The story of the Barberton Daisy, Gerbera jamesonii. Veld and Flora 65(4):114-115.

Coombs, S.V. 1936. South African plants for American gardens. Frederick. Stokes Co., New York.

Dental, J.B. 1921. Gerberas hybrides, race Dubois. Rev. Hort. 93:312.

Dubois, E. 1914. Gerbera hybride a fluers doubles. Rev. Hort. 86:348-349.

Dümmer, R.A. 1914. The South African gerberas. J. Royal Hort. Soc. 40:236-262.

Ewbank, H. 1895. Home correspondence. Gardeners' Chron. 18(14 Dec. 1895):719.

Fairbank, H. 1958. Gerberas. J. Royal Hort. Soc. 83:503-509.

Federal-State Market News Service. 1988. Marketing California ornamental crops. Calif. Dept. Food and Agr., USDA.

Florists' Exchange. 1905. Wholesale prices of cut flowers, New York, Jan. 6, 1905. Florists' Exchange 19(1):23.

Gallet, A. 1910. Le Gerbera jamesoni et ses hybrides. Rev. Hort. Beige Et Etrangere 36:69-70.

Gardeners' Chronicle. 1895. Notes from Cambridge Botanic Garden. Gardeners' Chron. 18(30 Nov. 1895):643.

Gardeners' Chronicle. 1907. Gerbera jamesoni. Gardeners' Chron. 41(1046):18.

Gardeners' Chronicle 1909. Hybrid gerberas. Gardeners' Chron. 45(1160):273, 290.

Hansen, H. V.1985. A taxonomic revision of the genus Gerbera (Composite, Mutisieae ) sections Gerbera, Parva, Piloselloides (in Africa), and Lasiopus. Opera Bet. 78.

Herrington, A. 1901. Gerbera jamesoni. Amer. Gardening 22(333):344-345.

Hindmarsh, W. T. 1902. Gerbera jamesoni. Gardeners' Chron. 32(818):182.

Hooker, J.D. 1889. Gerbera jamesoni. Curtis's Bet. Msg. 115(ser. 3.45):Tab. 7087. 
Jaenicke, A. 1908a. Gerbera jamesoni gigantea. Florists' Exch. 26(5):128.

Jaenicke, A. 1908b. Our readers' views. Florists' Exch. 26(12):397.

Jenkins, B. 1902. Home correspondence. Gardeners' Chron. 32(818):165.

Lamb, G. 1944. Gerbera jamesonii hybrids. J. Royal Hort. Soc. 69:74-75.

Lonsdale, E. 1908. Jottings for florists. Florists' Exch. 26(8):236.

Lynch, R.I. 1896. Gerbera viridifolia. Garden 49(1267):162.

Lynch, R.L 1902. Cambridge Botanic Garden. Gardener's Chron. 32(883):442.

Lynch, R.I. 1905. Gerbera, with a coloured plate of the new hybrids. Flora \& Sylva 3:206-208.

Lynch, R.I. 1906. Natural variations of Gerbera. Gardeners' Chron. 40(1036):314.

Lynch, R.I. 1909. Hybrid Gerberas. Gardeners' Chron. 45(1170):339-341.

Moss, C.E. 1930. Some natural hybrids of Clematis, Anemone, and Gerbera from the Transvaal. Proc. Linnean Soc. London. 141st Sess., 28 Feb. 1929. p. 3640.

Mottet, S. 1903. Gerbera jamesoni. Rev. Hort. 75:36-38.
Mücke, K.H. 1956. Gerberakultur undzuchtung in Holland. Gartenwelt 56:292293.

Netherlands Central Bureau of Statistics. 1992. Stat. Yrbk. 1992 of the Netherlands. SDU Publishers, The Hague, The Netherlands.

Nichols, H. 1902. Home correspondence. Gardeners' Chron. 31(806):377.

Post, K. 1949. Florist crop production and marketing. Orange Judd, New York.

Post, T.B. 1935. Notes on some diseases of ornamental. Plant Dis. Rptr. 19(7):98.

Quagliotti, L. and A. Baldi (eds.). 1979. Proc. Eucarpia Mtg. on genetics and breeding of carnation and gerbera. Alassio, Italy, Apr. 1978.

Review Horticole 1909. Les gerbera hybrides a Londres. Rev. Hort. 81:270.

Robinson,J.A. 1956. The modern Gerbera. N. Z. Gardener 12:591-593; 625-628; 695-698;786-791.

Rogers, M. N. and Tjia, B. 0.1990. Gerbera production for cut flowers and pot plants. Timber Press, Portland, Ore.

Royal Horticultural Society. 1891. General meeting notes of Nov. 101891. J. Royal Hort. Soc. vol. 13. p. CLXXVII and CXXI.
Smith, F.S. 1939. Control of cyclamen and broad mites on gerbera. USDA Circ. 516. $1-14$.

Sprenger, C. 1906. Die Gerbera. Gartenflora 55:13-16.

Tompkins, C.M. 1937. Foot rot of chinaaster, annual stock, and Transvaal daisy caused by Phytophthora cryptogea. J. Agr. Res. 55(8):563-574.

Veitch, J.H. 1906. Hortus Veitchii. James Veitch and Sons. Chelsea, England.

Vilmorin, P. 1906. Hortus Vilmorinianus. Paris.

Vilmorin, P. 1909. Hybrids of Gerbera jamesonii. Rev. Hort. 81:102-106.

Watson, W. 1906. Natural variations of Gerbera jamesoni. Gardeners' Chron. 40(1035):288.

Weston, T.A.. 1908. Stray notes from across the Atlantic. Florists' Exch. 26(11):364365.

Zimmernaan, P.E. and A.E. Hitchcock. 1934. Gerberas prove hardy in New York. Florists Exch. \& Hort. Trade World 86(16):18. 